Eva Strakošová, Eng. ${ }^{1}$

prof. Aleš Dudáček, Ph.D. ${ }^{1}$

Przyjęty/Accepted/Принята: 22.04.2014;

Zrecenzowany/Reviewed/Рецензирована: 19.02.2015;

Opublikowany/Published/Опубликована: 30.06.2015;

\title{
Effects of Firefighting Suit Contamination, within Selected Parameters, in Relation to Use during Emergency Interventions ${ }^{2}$
}

\author{
Skutki skażenia ubrania strażackiego podczas działań w sytuacjach nadzwyczajnych. \\ Analiza wybranych parametrów
}

\author{
Последствия загрязнения одежды пожарного, используемой во время \\ чрезвычайных действий. Анализ выбранных параметров
}

\begin{abstract}
Aim: The purpose of this article is to determine the protection parameters of the upper layer of a firefighting suit, by taking account of potential contamination of clothing and increased oxygen concentration in the local environment. The article is concerned with the determination of an oxygen index, with the support of laboratory test data, which identifies the burning behaviour and effectiveness of flame resistant clothing.

Introduction: A firefighting suit is designed to maximise the protection of firefighters engaged in emergency operations. For this reason materials used in the manufacture of protection clothing are being continuously improved. Current testing methods are used to determine protection parameters for clothing used in routine firefighting, rescue work and emergency interventions. However, these testing methods do not take account of issues associated with potential contamination of clothing re-used after prior interventions or used in exceptional circumstances. In the case of latter, an illustrative incident may include a situation where the immediate environment is exposed to an increased concentration of oxygen, caused by the leakage of liquefied oxygen. In such circumstances, more attention is necessary to the protection of operational firefighters, who usually wear standard firefighting suits. This article describes the results of laboratory tests that allow a better understanding of the risks.

Methodology: The current article deals with experiments conducted on specific materials used in the manufacture of firefighting suits, in accordance with established testing standards used for evaluation protective clothing, which are exposed to a source of radiant heat, using established methods for determining the transmission of heat after exposure to flames. Laboratory measurements were made with the aid of instruments used for the determination of an oxygen index at an ambient temperature according to the standard ČSN ISO 4589-2, and further at higher temperatures according to the standard ČSN ISO 4589-3. The Oxygen Index is, perhaps, the most economical and precise quality control test of combustible materials. This test is determined by the minimum percentage of oxygen in the test atmosphere that is required to marginally support combustion.

Conclusions: Experiment results reveal that after contamination of firefighting suits with oil or lubricating grease, the upper layer of the suit can burn if a flame is applied to the contaminated area. At the next stage it will be appropriate to focus on the behaviour of firefighting suits at higher temperatures. At increased temperatures, the value of oxygen concentration necessary for ignition is very low. Thermal analysis experiments were conducted with increased oxygen concentrations It was revealed that in an environment with increased oxygen concentration, even a clean firefighting suit is not a safety guarantee.
\end{abstract}

Keywords: firefighting suit, oxygen index, suit contamination

Type of article: original scientific article

\section{A BSTRAKT}

Cel: Celem artykułu jest określenie parametrów ochronnych warstwy zewnętrznej ubrania strażackiego przy uwzględnieniu potencjalnego skażenia ubrania oraz zwiększonego stężenia tlenu w atmosferze otoczenia. Przy wykorzystaniu wyników badań laboratoryjnych

\footnotetext{
Technical University of Ostrava, Czech Republic; eva.strakosova.st@vsb.cz;
}

2 The authors contributed equally to this article; 
w artykule podjęto próbę określenia indeksu tlenowego, na podstawie którego można scharakteryzować palność oraz skuteczność ubrań ognioodpornych.

Wstęp: Ubranie strażackie jest zaprojektowane tak, aby jak najskuteczniej chronić strażaków prowadzących działania w sytuacjach nadzwyczajnych. Dlatego materiały stosowane w produkcji ubrań ochronnych są stale doskonalone. Stosowane obecnie metody badawcze służą do określania parametrów ochronnych ubrań używanych w rutynowych działaniach gaśniczych, akcjach ratowniczych oraz sytuacjach nadzwyczajnych. Jednak metody te nie uwzględniają problemu potencjalnego skażenia ubrania użytego ponownie po wcześniejszej interwencji lub stosowanego w nietypowych warunkach. W tym ostatnim przypadku przykładowym zdarzeniem może być sytuacja, w której bezpośrednie otoczenie terenu działań strażackich jest narażone na zwiększone stężenie tlenu spowodowane wyciekiem płynnego tlenu. W takich okolicznościach większą uwagę należy zwrócić na zabezpieczenie strażaków biorących udział w akcjach, którzy zazwyczaj noszą standardowe ubrania strażackie. Artykuł opisuje wyniki badań laboratoryjnych, które pozwalają na lepsze zrozumienie związanych z tym problemem niebezpieczeństw.

Metodologia: Niniejszy artykuł przedstawia badania przeprowadzone na konkretnych materiałach używanych w produkcji ubrań strażackich, zgodnie z przyjętymi standardami badawczymi stosowanymi przy ocenie ubrań ochronnych, narażonych na źródło promieniowania cieplnego, przy użyciu przyjętych metod dla oceny przepływu ciepła pod wpływem działania ognia. Pomiary laboratoryjne wykonano z zastosowaniem narzędzi używanych do określenia indeksu tlenowego przy standardowej temperaturze otoczenia zgodnie ze standardem ČSN ISO 4589-2 oraz przy wyższych temperaturach zgodnie ze standardem ČSN ISO 4589-3. Indeks tlenowy jest prawdopodobnie najbardziej ekonomiczną i dokładną metodą oceny materiałów palnych. Technika zakłada pomiar minimalnej zawartości procentowej tlenu w badanej atmosferze, która może wpłynąć na zainicjowanie procesu spalania.

Wnioski: Badania wykazały, że warstwa zewnętrzna ubrania skażonego substancjami oleistymi i ropopochodnymi może się zapalić, jeśli płomień dotknie zanieczyszczonej powierzchni. Przy zwiększonej temperaturze wartość stężenia tlenu potrzebnego do zapłonu jest bardzo niska. W kolejnym kroku należy skupić się na zachowaniu ubrania strażackiego przy wyższych temperaturach. Eksperymenty wykorzystujące analizę termiczną przeprowadzono przy zwiększonej zawartości tlenu. Ich wyniki pokazały, że w środowisku ze zwiększonym stężeniem tlenu nawet czyste ubranie strażackie nie jest gwarantem bezpieczeństwa.

Słowa kluczowe: ubranie strażackie, indeks tlenowy, skażenie ubrania strażackiego

Typ artykułu: oryginalny artykuł naukowy

\section{АННОТАЦИЯ}

Цель: Цель статьи - определить защитные параметры внешнего слоя одежды пожарного с учётом возможного её загрязнения и повышенной концентрации кислорода в окружающей среде. Используя результаты лабораторных исследований, в статье была сделана попытка определения кислородного индекса, на основе которого можно охарактеризовать воспламеняемость и эффективность огнестойкости одежды.

Введение: Одежду пожарного проектируют для наиболее эффективной защиты пожарного, осуществляемого деятельность во время чрезвычайных ситуаций. Поэтому, материалы, используемые в производстве защитной одежды, всё время совершенствуются. Новейшие исследовательские методы позволяют определять защитные параметры одежды, используемой в повседневной деятельности пожарных, при спасательных работах и чрезвычайных ситуациях. Однако, эти методы не учитывают возможного загрязнения одежды после ранее проведенной интервенции или вследствие нетипичных условий. Так примером последнего может быть ситуация, когда в воздухе вокруг действий пожарных повышена концентрация кислорода вследствие его утечки в жидкой форме. В таких условиях большое внимание следует обратить на защиту пожарных, учавствующих в действиях, которые, чаще всего, одеты в стандартную одежду. Статья описывает результаты лабораторных исследований, которые позволяют лучше понять проблемы, связанные с этими опасностями.

Методология: Данная статья представляет эксперименты, проведенные на конкретных материалах, которые используются в производстве пожарной одежды, согласно принятым стандартам исследований, принимаемым при оценке защитной одежды, которая подвержена воздействию источника теплового излучения, используя общепринятые методы для оценки теплового потока под воздействием огня. Лабораторные исследования были проведены с использованием инструментов, принимаемых для определения кислородного индекса при стандартной температуре среды согласно стандарту ČSN ISO 4589-2, и при высших температурах согласно стандарту ČSN ISO 4589-3. Кислородный индекс является, вероятнее всего, самым экономическим и точным методом оценки горючих материалов. Техника включает в себя измерение минимального процентного содержания кислорода в исследуемой атмосфере, которое может повлиять на инициацию процесса горения.

Выводы: Исследования показали, что внешний слой пожарной одежды, загрязненной масляными и нефтепроизводными веществами, может воспламениться, если пламя коснется загрязненной поверхности. При повышенной температуре, значение концентрации кислородабнужного для воспламенения есть очень низкое. Далее следует уделить внимание поведению одежды пожарного при высших температурах. Эксперименты, использующие тепловой анализ, были проведены при повышенной концентрации кислорода. Их результаты показали, что в среде с повышенной концентрацией кислорода, даже чистая одежда пожарного не гарантирует безопасности.

Ключевые слова: одежда пожарного, кислородный индекс, загрязнение одежды пожарного

Вид статьи: оригинальная научная статья 


\section{Introduction}

The personal experience of each firefighter during an operational incident has a significant impact on the progress of the intervention. In order to avoid physical injury, an operational firefighter should be adequately protected by a suitable firefighting suit. Protective clothing must fulfil strict safety requirements and protect the firefighter in a range of situations.

This article is a part of experimental research into the behaviour of fabrics and series of material layers used in the manufacture of firefighting suits. It addresses the problem of consequences associated with potential contamination of clothing from prior operations and issues emerging during incidents where increased oxygen concentration occurs as a result of liquefied oxygen leakage into the surrounding atmosphere. In circumstances where the $\mathrm{O}_{2}$ concentration has increased, a fire risk is higher than that at standard $\mathrm{O}_{2}$ concentration. Therefore, firefighters normally equipped with standard firefighting suits should be afforded corresponding protection when operating in a more intense hazardous environment. Illustrations of such environments include: a tragic fire at a retirement home caused by a defect in an oxygen concentrator [7], accidents involving leakage of liquefied oxygen in hospitals [8] accidents during space travel - most notably Apollo 1 [9].
The aim of this article is to determine fire resistance parameters of the upper layer of a firefighting suit, supported by results derived from laboratory experiments, with a focus on the degree of suit contamination and oxygen concentration in the local environment. The outcome provides data about burning behaviour and effectiveness of flame-resistant clothing and the determination of an oxygen index.

\section{Experiment}

\subsection{Preparation}

Experiments were performed in the laboratories at the Faculty of Safety Engineering of VŠB - Technical University of Ostrava. Three types of firefighting suits were selected for examination (see Table. 1), namely suits TigerPlus and Premium 20 from the company DEVA F-M, s.r.o., Frýdek - Místek [1] and suits GoodPRO FR3 FireHorse from the company VOCHOC, s.r.o., Pilsner [2]. Only the upper layers of firefighting suits were exposed to the tests. The choice of samples was influenced by two factors [6]. The first is that these suits are most widely used in the Fire and Rescue Service of the Czech Republic [3] and secondly that they were also used in a series of tests conducted in a flashover container at Zbiroh in June 2012 and October 2013.

Table 1. Material composition of the upper layer of firefighting suits

\begin{tabular}{|l|c|c|c|}
\hline \multicolumn{1}{|c|}{ Material composition of upper layer } & Suit type & Grammage (g.m $\left.\mathbf{~}^{-2}\right)$ & Company \\
\hline NOMEX DIAMOND Ultra - SOFIGUARD & TIGER Plus & 210 & DEVA F-M, s. r. o. \\
\hline $\begin{array}{l}\mathbf{5 3} \% \text { KERMEL, 39\% Lenzing FR, 6\% Technora, } \\
\text { 2\% carbon fibre, RipStop weave }\end{array}$ & $\begin{array}{c}\text { GoodPRO FR3 } \\
\text { FireHorse }\end{array}$ & 230 & VOCHOC, s. r. o. \\
\hline DIAMOND FORCE - SOFIGUARD & Premium 20 & 245 & DEVA F-M, s. r. o. \\
\hline
\end{tabular}

Source: Own elaboration.

External conditions were always recorded before the experiment. Laboratory temperature was kept at $(23 \pm 2)^{\circ} \mathrm{C}$ and air humidity moved within the range of (32.2 - 67.2)\%. For oxygen index determination, samples sizes of $140 \times 52 \mathrm{~mm}$ were cut and coated with a layer of grease before the experiment. Contamination sources which could be encountered by firefighters during incidents were identified. In our experiments these were oil and lubricating grease. Samples were contaminated with standard yearround motor oil and lubricating grease A4 (plastic grease for gudgeon and antifriction bearing lubrication). Oil was mixed with hexane and sprayed on to the material. After a period of time hexane evaporated. The samples were covered with filter paper and dried at $60^{\circ} \mathrm{C}$ in a horizontal position to a constant mass. The application of lubricating grease was tested in two ways, namely by mixing it with hexane and using brushes and spatulas (without the use of a solvent). The latter method appeared to be better, by providing a more even layer of grease. Average amounts of applied grease are given in Table. 1. For comparison, two quantities of lubricating grease A4 were used; the larger quantity is designated as A4 - higher grammage. The samples were prepared and kept in the laboratory at standard conditions and were always weighted before testing. Samples were prepared twice with an endeavour to achieve the same degree of coverage in both instances. Table 2 indicates better grease coverage. 
Table 2. Mass samples with grease

\begin{tabular}{|c|c|c|c|c|c|c|c|c|}
\hline \multirow[b]{2}{*}{ Applied grease } & \multicolumn{4}{|c|}{ NOMEX DIAMOND Ultra } & \multicolumn{4}{|c|}{ KERMEL/LENZING FR/TECHNORA } \\
\hline & $\begin{array}{c}\text { clean } \\
\text { sample } \\
(\mathrm{g})\end{array}$ & $\begin{array}{l}\text { applied } \\
\text { grease } \\
(\mathrm{g})\end{array}$ & $\begin{array}{c}\text { applied } \\
\text { grease } \\
(\%)\end{array}$ & $\begin{array}{l}\text { applied } \\
\text { grease } \\
\left(\mathrm{g} / \mathbf{m}^{2}\right)\end{array}$ & $\begin{array}{c}\text { clean } \\
\text { sample } \\
(\mathrm{g})\end{array}$ & $\begin{array}{l}\text { applied } \\
\text { grease } \\
\text { (g) }\end{array}$ & $\begin{array}{l}\text { applied } \\
\text { grease } \\
(\%)\end{array}$ & $\begin{array}{c}\text { applied } \\
\text { grease } \\
\left(\mathbf{g} / \mathbf{m}^{2}\right)\end{array}$ \\
\hline Oil & \multirow{2}{*}{1.513} & 0.509 & 25.173 & 69.959 & \multirow{2}{*}{1.716} & 0.565 & 24.770 & 77.610 \\
\hline A4 & & 0.580 & 27.711 & 79.670 & & 0.648 & 27.411 & 89.011 \\
\hline Oil & \multirow{3}{*}{1.513} & 0.404 & 21.075 & 55.426 & \multirow{3}{*}{1.716} & 0.568 & 24.869 & 78.022 \\
\hline A4 & & 0.594 & 28.192 & 81.613 & & 0.592 & 25.650 & 81.319 \\
\hline A4 - higher grammage & & 0.900 & 37.298 & 123.626 & & 0.900 & 34.404 & 123.626 \\
\hline
\end{tabular}

Source: Own elaboration.

\subsection{Measurement Procedure}

The Oxygen Index is, perhaps, the most economical and precise quality control test of combustible materials. This test is determined by the minimum percentage of oxygen in the test atmosphere that is required to marginally support combustion.

Laboratory measurements were performed with the aid of instruments (see Fig. 1) to determine an oxygen index at an ambient temperature in accordance with the standard ČSN ISO 4589-2 [4], where the oxygen index (OI) corresponds numerically to the minimum oxygen concentration by volume percent in an oxygen-nitrogen mixture at a temperature of $(23 \pm 2)^{\circ} \mathrm{C}$. Such conditions allow for burning of materials under prescribed testing conditions.

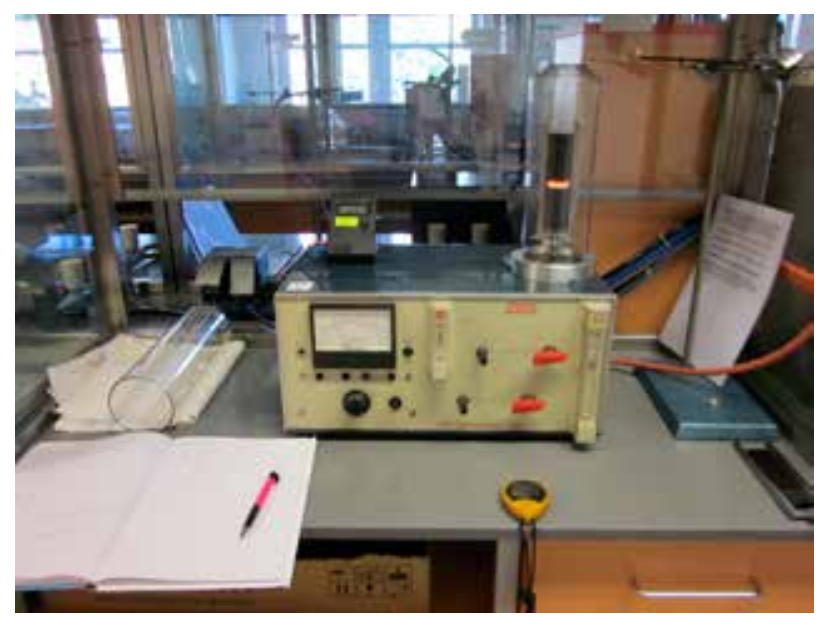

Fig. 1a. Apparatus for the determination of oxygen index at standard temperature

Source: Own elaboration.

If the duration of burning or its extent did not exceed the prescribed values, the duration and extent were recorded with a designated response "O". However, if the duration of burning or its extent exceeded the relevant limiting value, the result was recorded with a designated response " $\mathrm{X}$ " [5], see Table 3 .

The oxygen index was calculated according to a relation: $\mathrm{OI}=\mathrm{c}_{\mathrm{f}}+\mathrm{k} \cdot \mathrm{d}$,
Further measurements were performed at higher temperatures in accordance with the standard ČSN ISO 4589-3 [5], where the oxygen index (henceforth referred to as OI) corresponds numerically to the minimum oxygen concentration by volume percent in an oxygen-nitrogen mixture at a temperature higher than $25^{\circ} \mathrm{C}$, at which the material still burns under prescribed testing conditions. The test sample was held in a steel holder and inserted into a test tube. Furthermore, the required concentration of oxygen in the nitrogen mixture was set and the flow rate of the gas mixture was adjusted. In elevated-temperature tests, the test sample was pre-heated in a testing column for $(240 \pm 10) \mathrm{s}$ to achieve the test temperature in given tolerances before ignition. The samples were ignited by the method B - ignition supporting vertical burning and the burner flame was kept for a maximum of $30 \mathrm{~s}$.

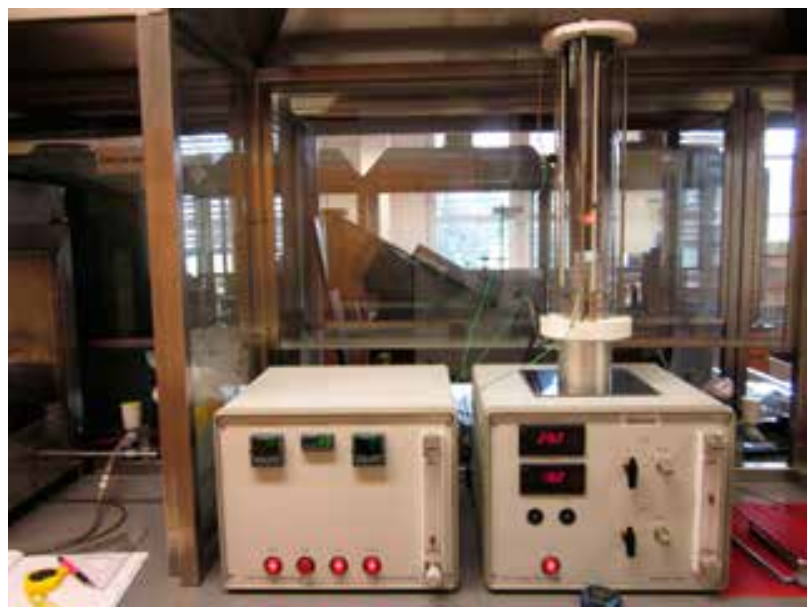

Fig. 1b. Apparatus for the determination of oxygen index at elevated temperature

Source: Own elaboration.

where $c_{f}$ is the final value of oxygen concentration used in a series of measurements $\mathrm{N}_{T}$

$\mathrm{d}$ - interval between oxygen concentrations

$\mathrm{k}$ - constant obtained from ČSN ISO 4589-2 [4]

$\mathrm{N}_{\mathrm{T}}, \mathrm{N}_{\mathrm{L}}$ - series of measurements according to ČSN ISO 4589-2 [4]

$\mathrm{N}_{\mathrm{L}}$ - first series of measurements until were not recorded response of " $\mathrm{X}$ " and " $\mathrm{O}$ ". 
Measurement continues from the last sample of this series of measurements.
Measurements begin with preliminary concentration determination, which do not differ by more than $1 \%$ concentration of $\mathrm{O} 2$.

Table 3. Example of evaluation of measurement of a clean sample of NOMEX DIAMOND Ultra at $120^{\circ} \mathrm{C}$

\begin{tabular}{|l|c|c|}
\hline \multicolumn{1}{|c|}{ Clean sample NOMEX DIAMOND Ultra } & 22.8 & 23.8 \\
\hline Concentration of O2 (\%) & 32 & 122 \\
\hline Burning time (s) & 25 & 100 \\
\hline Burned length (mm) & $\mathrm{O}$ & $\mathrm{X}$ \\
\hline Response (X or O) & & \\
\hline
\end{tabular}

\begin{tabular}{|c|c|c|c|c|c|c|c|}
\hline \multirow{3}{*}{ NOMEX DIAMOND Ultra } & \multicolumn{7}{|c|}{ Determination of value of oxygen index } \\
\hline & \multicolumn{7}{|c|}{ series $\mathbf{N}_{\mathrm{T}}$} \\
\hline & \multicolumn{2}{|c|}{ Series $\mathbf{N}_{\mathrm{L}}$} & \multirow[b]{2}{*}{23.6} & \multirow[b]{2}{*}{23.8} & \multirow[b]{2}{*}{23.6} & \multirow[b]{2}{*}{23.8} & \multirow{2}{*}{$\begin{array}{c}\mathbf{c}_{\mathbf{f}} \\
23.6 \\
\end{array}$} \\
\hline Concentration of O2 (\%) & 23.8 & 23.6 & & & & & \\
\hline Burning time (s) & 122 & 80 & 80 & 120 & 74 & 119 & 76 \\
\hline Burned length $(\mathrm{mm})$ & 100 & 55 & 55 & 100 & 60 & 100 & 60 \\
\hline Response $(\mathrm{X}$ or $\mathrm{O})$ & $\mathrm{X}$ & $\mathrm{O}$ & $\mathrm{O}$ & $\mathrm{X}$ & $\mathrm{O}$ & $\mathrm{X}$ & $\mathrm{O}$ \\
\hline
\end{tabular}

Source: Own elaboration.

Actual measurements were carried out at various temperatures. The first measurement was made at a standard temperature, the average of which was determined at $24^{\circ} \mathrm{C}$. Other measurements were performed at higher levels of $60^{\circ} \mathrm{C}, 120^{\circ} \mathrm{C}$ and $180^{\circ} \mathrm{C}$. Altogether, 365 samples were measured. One series of measurements of material of a firefighting suit contained 10 samples, see Fig. 2. Each material was measured once at different temperatures and types of pollution.

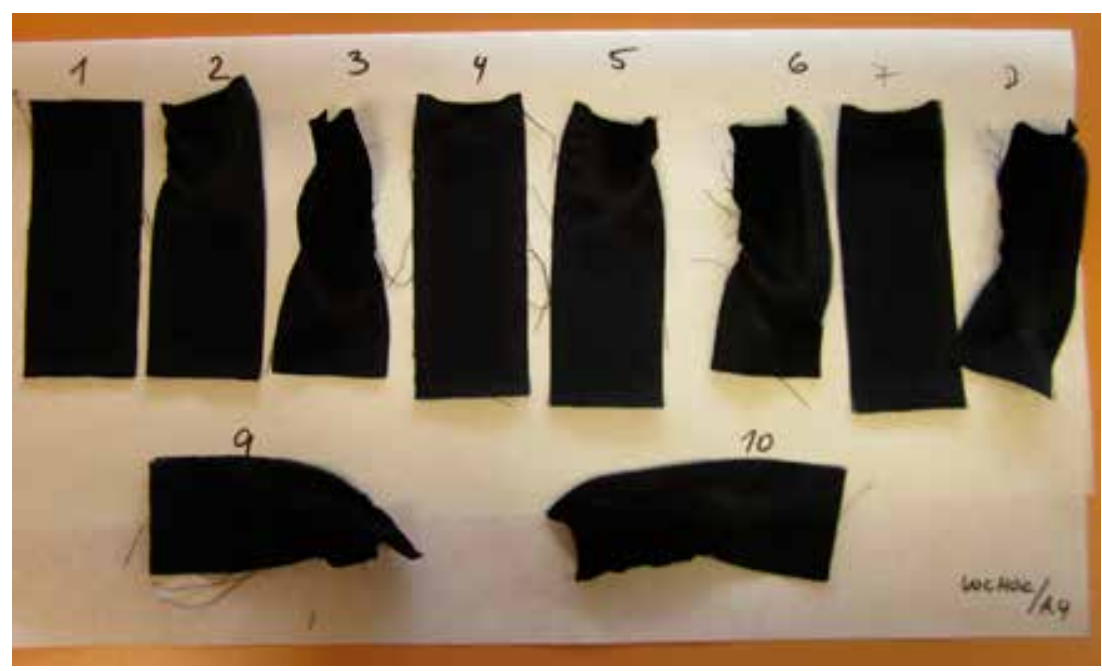

Fig. 2. Example of KERMEL/LENZING FR/TECHNORA samples with lubricating grease $\mathrm{A} 4$ after measurement at $180^{\circ} \mathrm{C}$ Source: Own elaboration.

\section{Results}

The measuring exercise revealed a range of oxygen index values at temperatures of $24^{\circ} \mathrm{C}, 60^{\circ} \mathrm{C}, 120^{\circ} \mathrm{C}$ and $180^{\circ} \mathrm{C}$ and these are presented in Tables 4, 5 and 6. From obtained results it is evident that, in the case of clean suits, the oxygen index is higher than $21 \%$, even at higher temperatures (Fig. 4). For a better comparison of the materials the results were illustrated in Figure 3. Therefore, the samples do not burn in standard conditions at all tested temperature levels.
A different situation occurs when suits are contaminated. In these circumstances tested materials burned even at oxygen concentrations of less than $21 \%$. Of course, it is true that the higher the air temperature, the lower is the oxygen concentration necessary for burning (Figs. 4, 5 and 6). Moreover, there is also a dependence on the level of contamination, where the quantity of contamination increases the required oxygen concentration decreases. 
Table 4. Results of measurement of oxygen index of NOMEX DIAMOND Ultra samples

\begin{tabular}{|l|c|c|c|c|}
\hline \multicolumn{1}{|c|}{ NOMEX DIAMOND Ultra } & $\mathbf{2 4}^{\circ} \mathbf{C}$ & $\mathbf{6 0}^{\circ} \mathbf{C}$ & $\mathbf{1 2 0}^{\circ} \mathbf{C}$ & $\mathbf{1 8 0}^{\circ} \mathbf{C}$ \\
\hline clean & 26.1 & 24.9 & 23.7 & 22.3 \\
\hline oil & 20.3 & 19.7 & 18.5 & 17.3 \\
\hline lubricating grease A4 & 19.2 & 18.9 & 17.7 & 17.4 \\
\hline lubricating grease A4+ & $-{ }^{*}$ & 18.6 & 17.1 & $-{ }^{*}$ \\
\hline
\end{tabular}

Note: ${ }^{*}$ - measurements were not performed

Source: Own elaboration.

Table 5. Results of measurement of oxygen index of KERMEL/LENZING FR/TECHNORA samples

\begin{tabular}{|l|c|c|c|c|}
\hline \multicolumn{1}{|c|}{ KERMEL/LENZING FR/TECHNORA } & $\mathbf{2 4}^{\circ} \mathbf{C}$ & $\mathbf{6 0}^{\circ} \mathbf{C}$ & $\mathbf{1 2 0}^{\circ} \mathbf{C}$ & $\mathbf{1 8 0}^{\circ} \mathbf{C}$ \\
\hline clean & 29.3 & 27.2 & 25.7 & 23.5 \\
\hline oil & 20.7 & 20.3 & 18.7 & 17.6 \\
\hline lubricating grease A4 & 19.4 & 19.7 & 18.0 & 17.6 \\
\hline lubricating grease A4 + & $-{ }^{\star}$ & 18.9 & 17.3 & $-^{\star}$ \\
\hline
\end{tabular}

Note: ${ }^{\star}$ - measurements were not performed

Source: Own elaboration.

Table 6. Results of measurement of oxygen index of DIAMOND FORCE samples

\begin{tabular}{|l|c|c|c|c|}
\hline \multicolumn{1}{|c|}{ DIAMOND FORCE } & $\mathbf{2 4}^{\circ} \mathbf{C}$ & $\mathbf{6 0}^{\circ} \mathbf{C}$ & $\mathbf{1 2 0}^{\circ} \mathbf{C}$ & $\mathbf{1 8 0}^{\circ} \mathbf{C}$ \\
\hline clean & 30.7 & 28.6 & 27.3 & 26.3 \\
\hline oil & 22.5 & 21.4 & 19.3 & 18.7 \\
\hline lubricating grease A4 & 20.7 & 19.6 & 17.9 & 17.1 \\
\hline
\end{tabular}

Source: Own elaboration.

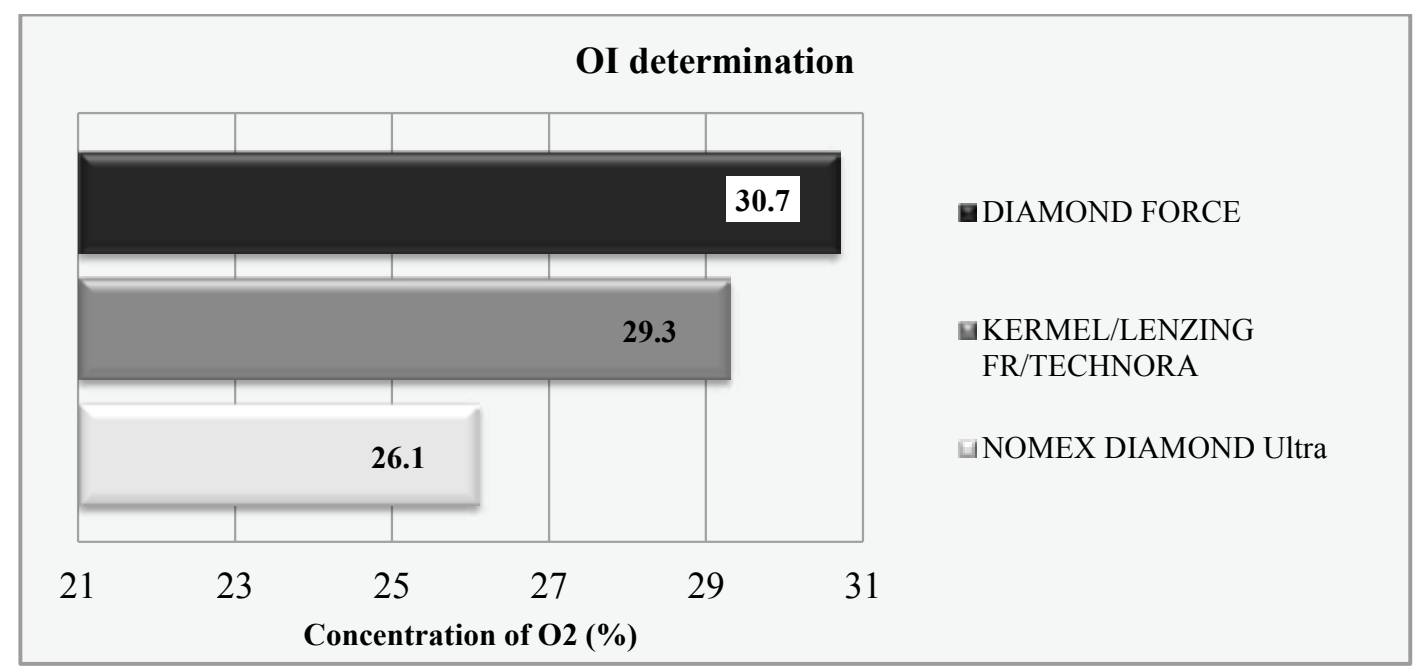

Fig. 3. Comparison of oxygen index of samples of clean firefighting suits at ambient temperature of $24^{\circ} \mathrm{C}$ Source: Own elaboration. 


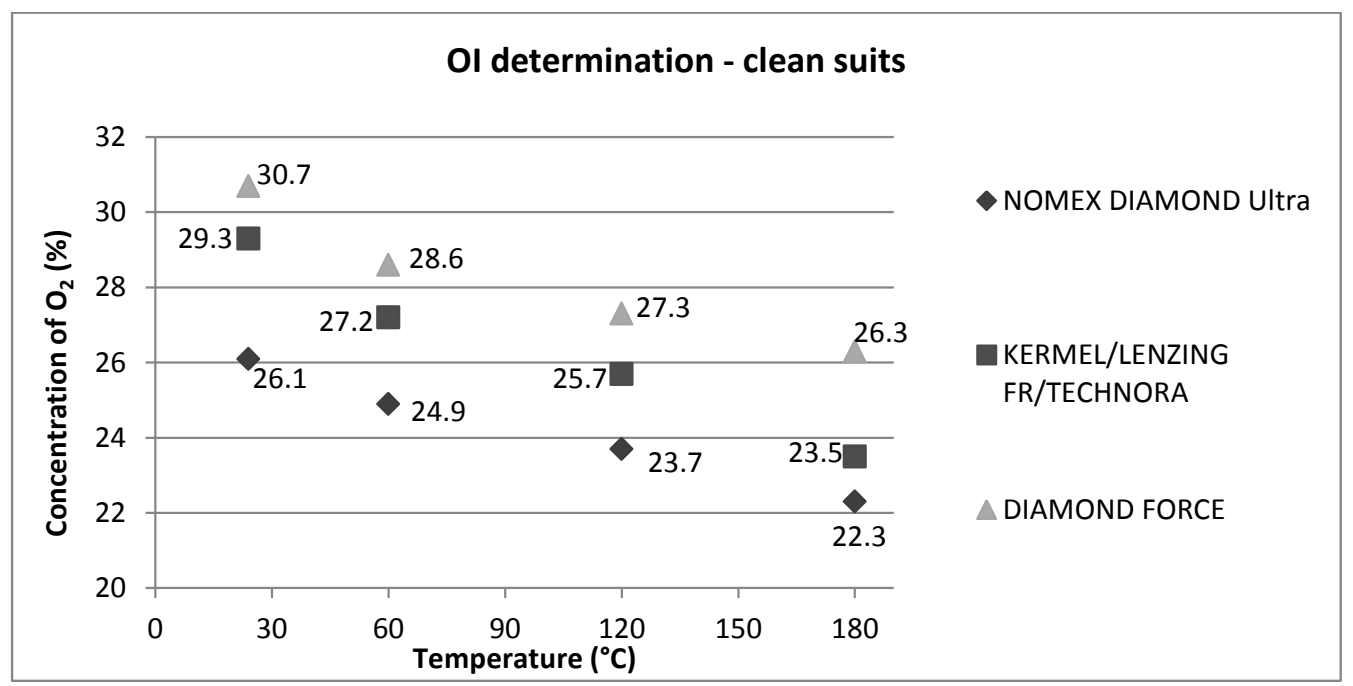

Fig. 4. Comparison of oxygen index of samples of clean firefighting suits at selected temperatures Source: Own elaboration.

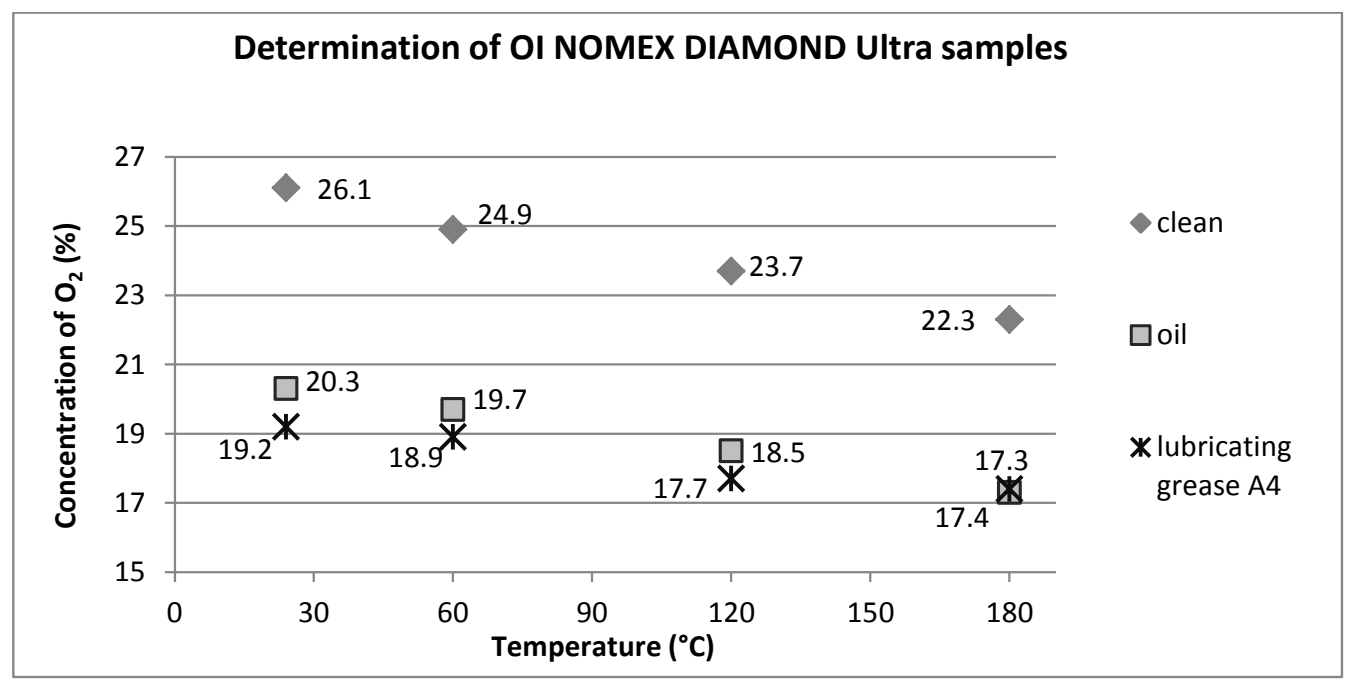

Fig. 5. Comparison of oxygen index of NOMEX DIAMOND Ultra samples at selected temperatures Source: Own elaboration.

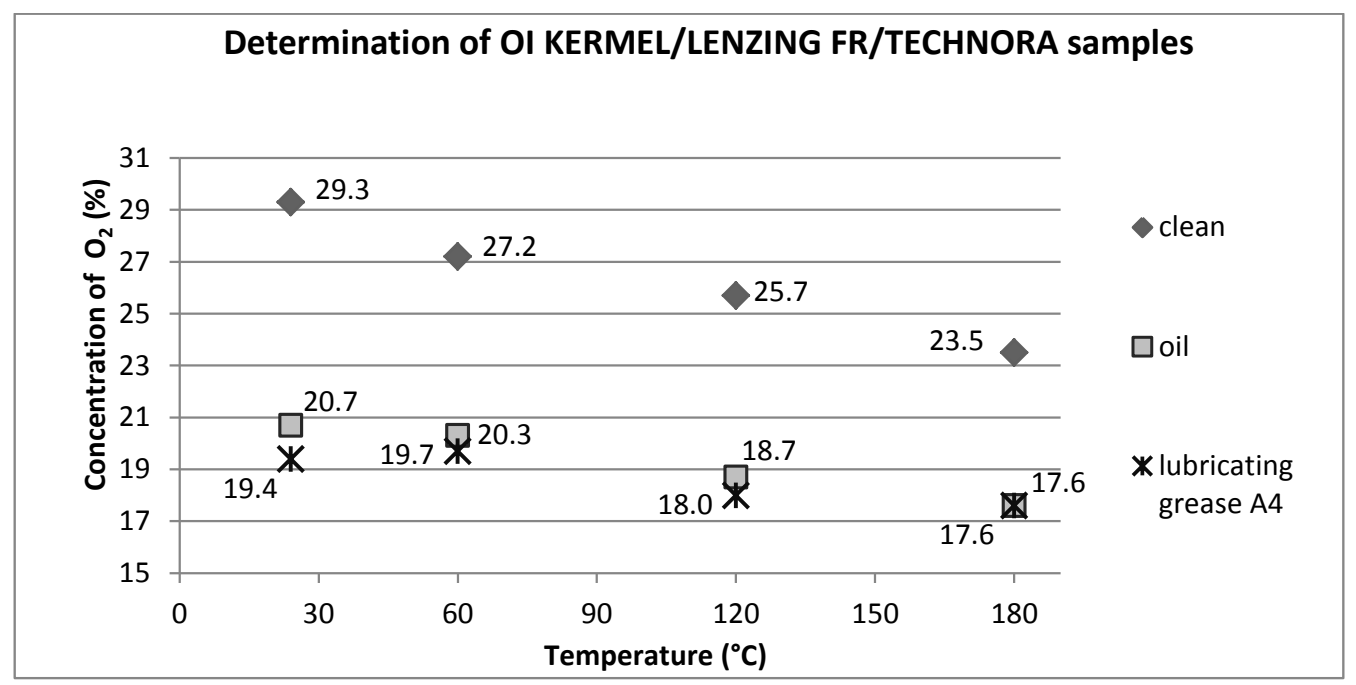

Fig. 6. Comparison of oxygen index of KERMEL/LENZING FR/TECHNORA samples at selected temperatures Source: Own elaboration. 


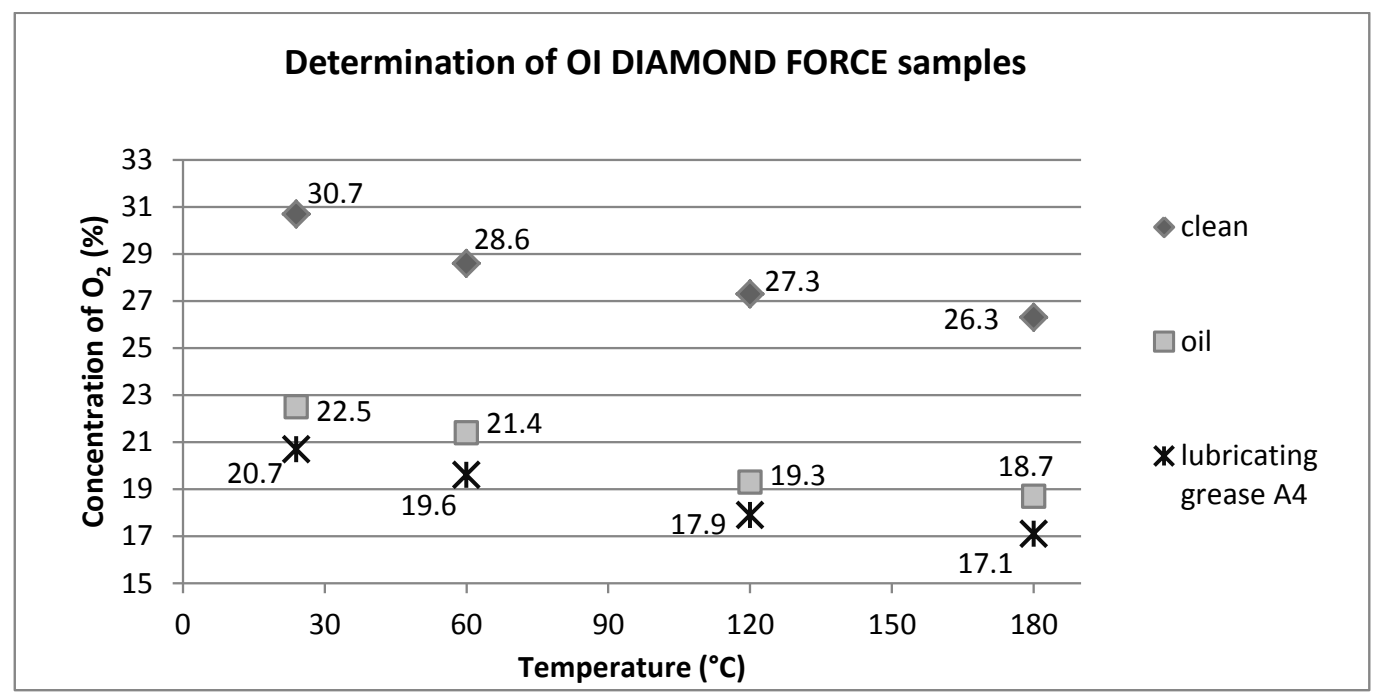

Fig. 7. Comparison of oxygen index of DIAMOND FORCE samples at selected temperatures Source: Own elaboration.

\section{Discussion}

The hypothesis concerning higher temperatures demonstrates that the value of oxygen index decreases. Test results reveal that samples from DIAMOND FORCE exhibit higher oxygen index values at a standard temperature (see Fig. 7) and also at higher temperatures compared with samples from NOMEX DIAMOND Ultra and KERMEL/ LENZING FR/TECHNORA. Nevertheless, the value of oxygen index in almost all contaminated samples (but oil contamination at $60^{\circ} \mathrm{C}$ in a sample of DIAMOND FORCE) was below the limit of $21 \% \mathrm{O}_{2}$ and thus the contaminated area of the firefighting suit could be ignited on contact with and during subsequent action of a flame source. The contaminated material was deformed during testing, see Fig. 2, and ripped at $60^{\circ} \mathrm{C}$ temperature level of the oxygen-nitrogen mixture. Moreover, results reveal that at a temperature level of $180^{\circ} \mathrm{C}$, the differences between oxygen index values of individual contaminated materials are almost blurred.

The biggest problem, evident before measurement, was the application of grease to samples. The initial method selected for suit contamination, by spraying oil mixed with hexan, is not appropriate, because this did not always guarantee the same surface coverage of applied grease in all prepared samples and thus the method was difficult to replicate. Although a $29 \%$ deviation was achieved in the application of grease this did not have a significant impact on the determination of OI. Nevertheless, this issue should also be addressed in the future and it is anticipated that more sophisticated technology, for grease application, will make it possible to prepare better quality samples.

\section{Conclusion}

Measurement results reveal that after contamination of firefighting suits, with oil or lubricating grease, the upper layer of suits can burn if a flame is applied to the contaminated area. At higher temperatures, the values of oxygen concentration necessary for ignition decrease $\left(\right.$ at $180^{\circ} \mathrm{C}$, OI moves in a range of $17.1-17.6$ ).

Interventions in an environment with increased oxygen concentration pose additional hazards and a "clean" firefighting suit is not a guarantee for safety. In situations where oxygen concentration is higher than $30.7 \%$, the suit can ignite at a standard temperature of $24^{\circ} \mathrm{C}$. At a temperature of $120^{\circ} \mathrm{C}$ the concentration of oxygen necessary for ignition of KERMEL/LENZING FR/ TECHNORA samples decreases to below $26 \%$ and that of NOMEX DIAMOND Ultra samples even further, to below $24 \%$.

In the next stage of research it will be appropriate to focus on, and extend knowledge about the behaviour of firefighting suits at higher temperatures. Additionally, further work is planned for the completion of measurements and thermal analysis at higher concentration levels of oxygen.

\section{Project relevance}

This article was written with support from the grant SGS No. SP2013/187 "Experimental research into the behaviour of fabrics and whole series of material layers of firefighting suits, in various conditions of thermal load and other environmental parameters, and determination of limits in use of material utilised in prior operations, as well as firefighter's comfort". 


\section{References}

[1] DEVA F-M s.r.o. Sortiment 2010, [electr. doc.] http://www. deva-fm.cz/sortiment.php [accessed: 10.05.2013].

[2] Vochoc s.r.o. Produkty 2011, [electr. doc.] http://www. vochoc.cz/ochrana-proti-teplu/produkty.php [accessed: 10.05.2013].

[3] Prokeš O., Rozbor tepelné zátěže zásahového oděvu pro hasiče při výcviku. Diplomová práce, Ostrava: VŠB - TU, Ostrava 2012, p. 63.

[4] ČSN ISO 4589-2 Plasty - Stanovení hořlavosti metodou kyslikového čísla: Část 2: Zkouška při teplotě okolí. Český normalizační institute, Praha 1998.

[5] ČSN EN ISO 4589-3 Plasty-Stanovení hořlavosti metodou kyslikového čisla - Část 3: Zkouška při zvýšené teplotě, Český normalizační institute, Praha 1998.

[6] Jánošík L. et al.,. Závěrečná zpráva SGS SP2012/13: Vliv různé tepelné zátěže na mikroklima hasiče $v$ zásahovém oděvu a na vybrané fyziologické parametry hasiče. VŠB - TU, Ostrava 2013.
[7] Tomaškovič J., Za tragický požár v domově důchodců mohl prístroj na kyslik, in: Novinky.cz [eletrc. doc.] http://www. novinky.cz/krimi/313018-za-tragicky-pozar-v-domoveduchodcu-mohl-pristroj-na-kyslik.html [accessed: 12 . 01.2014].

[8] Ahrens M., Fires and Burns Involving Home Medical Oxygen, in: Nfpa.org. [electr. doc.] http://www.nfpa.org/ /media/ Files/Research/Fact\%20sheets/oxygenfactsheet.pdf [accessed: 12.01.2014].

[9] Pacner K., Před 45 lety: Za 14 sekund kabina Apolla 1 pukla žárem. Uvnitř neměli šanci, in: IDNES.cz: Technet.cz [electr. doc.] http://technet.idnes.cz/pred-45-lety-za-14-sekundkabina-apolla-1-pukla-zarem-uvnitr-nemeli-sanci-1jw-/ tec_vesmir.aspx?c=A120126_175519_tec_vesmir_mla [accessed: 12.01.2014].

\begin{abstract}
Aleš Dudáček - a professor at Department of Fire Protecting Engineering and Industrial Safety, Faculty of Safety Engineering, VŠB - Technical University of Ostrava. From 2002 to 2009 he was the dean of the Faculty of Safety Engineering. His research and project work focused on the fire safety equipment. He is an author and co-author of many articles, especially proceedings of scientific conferences.
\end{abstract}

Eva Strakošová - graduated from the VŠB - Technical University of Ostrava, Faculty of Safety Engineering in 2012. Currently she is undertaking $\mathrm{PhD}$ studies at the same university. Her current research interests include the relationship between fabric parameters of firefighting suits, their design and utilization during firefighting operations. 